\title{
THE STATUS OF JERUSALEM: SOME NATIONAL AND INTERNATIONAL ASPECTS
}

\author{
S. Shepard Jones*
}

I

Scope AND PuRpose

If a genuine Arab-Israeli peace settlement is to be achieved as an aftermath to the 1967 war and the subsequent diplomatic efforts of the United Nations in Ig67 and 1968, some understanding must be reached on the future status of Jerusalem. Of course, this is only one of many troublesome questions that evoke political malaise. The purpose of this short essay is to put the problem of Jerusalem in perspective by drawing attention to some of the background considerations that shed light on the present situation. These considerations are as much political as legal; they are both national and international, religious and secular. While the purpose is primarily to provide perspective, not to argue for a particular resolution of the future status of Jerusalem, this article does conclude with an indication of the direction and spirit within which a settlement might be sought, if the interests of all the parties are to be protected. These interests are complex and varied, and it is assumed that the cause of international peace and justice demands respect for the interests of all concerned and therefore not the complete triumph of the purposes of any one nation or religious community. The multiple interests in Jerusalem suggest the wisdom of redefining national purposes to the higher good.

II

The Nature of "The Question of Jerusalem, ig67-68"

The more restricted "problem of Jerusalem" in its present context arises out of the suddenly upset military balance and the emotional shock produced by the lightning-like war of June 1967 . A part of that reality-but not its beginning ${ }^{1}$-was the attack by Jordanian forces on Israel on June 5, following the outbreak of war on the Egyptian-Israeli front earlier the same day. After hard fighting there followed, on June 7, the capture of Arab Jerusalem, governed by Jordan since I948, and Israel's announcement of June $28^{2}$ that "the law, jurisdiction and administration of the

- A.B. 1930, Georgetown College; A.M. 1931, University of Kentucky; Ph.D. (Rhodes Scholar) 1936, Oxford University. Burton Craige Professor of Political Science, University of North Carolina. Author, The Scandinavian States and the League of Nations (1939); co-editor [with D. P. Myers], Docoments on AMerican Foreign Relations (vols. I-III (1939, 1940, I94I); AMerica's Role in the MimdLe EAST (1958).

${ }^{2}$ M. Howard \& R. Hunter, Israel and the Arab World: The Crisis of 1967 (Adelphi Papers, no. 41, October 1967); Yost, The Arab-Israeli War: How It Began, 46 Foreign AFF. 304-06 (I968).

${ }^{2}$ Under ordinance of the preceding day. Summaries at p. 8 of the Report of the Secretary-General under General Assembly resolution 2254(ES-I), U.N. Doc. A/6793, Sept. 12, 1967. Also issued as U.N. Doc. $s / 8 r_{4} 6$. 
State of Israel" were being applied to the Old City and to an enlarged East Jerusalem, as Arab Jerusalem is now designated.

Bitter protest came from Jordan ${ }^{3}$ and other Arab states and from non-Arab states inclading the United States, ${ }^{4}$ and allegations that international law had been violated by Israel. Israel asserted that Jordan was responsible for initiating the attack on Jerusalem and must accept the consequences. ${ }^{5}$

The United Nations General Assembly adopted two resolutions without opposition on July 4 and 14,1967 (the latter by a vote of one hundred to zero, with eighteen abstentions, including that of the United States ${ }^{6}$ ), declaring Israel's action "invalid," and calling upon Israel "to rescind all measures already taken and desist forthwith from taking any action which would alter the status of Jerusalem." Israel refused to comply, contending that "no international or other interest would be served by the institution of divisions and barriers which would only sharpen tension and generate discrimination." The claim was made that Israel was responding to "the intrinsic necessity of ensuring equal rights and opportunities to all the city's residents." This answer did not meet the major issue at stake, as the General Assembly debate made clear. ${ }^{9}$

Looking ahead, the Israeli Government stated that its policy of integrating all of Jerusilem "does not foreclose the final settlement of certain important aspects of the Jerusalem situation which lie at the origin of the international interest in the city." Reference was made to "the need to secure appropriate expression of the special interest of the three great religions in Jerusalem." But this statement seemed to azknowledge the concerns and interests of others as something to be considered in the future, since the Foreign Minister added: "I am confident that in an atmosphere of international tranquility substantial progress could be made toward this aim, which has hitherto had no concrete fulfillment." ${ }^{\text {"10 }}$ Reference was here made,

"See, e.g., remarks of King Hussein, U.N. Doc. A/PV. 1536 , June 26,1967 , at 11 .

'See, e.g., remarks of U.S. Delegation, U.N. Doc. A/PV. 1546 , July 3, 1967, at 8-10.

${ }^{5}$ The Israeli Foreign Minister stated to the General Assembly on June 19, 1967:

"While fighting raged on the Egyptian-Israel frontier and on the Syrian front, we still hoped to contain the conflict. Jordan was given every chance to remain outside the struggle. Even after Jordan had bombarded and bombed Israel territory at several points, we still proposed to the Jordanian monarch that- he abstain from any continuing hostilitics . . . .

"... Jordan's responsibility for the second phase of the concerted aggression is cstablished bcyond doubt. Surely this responsibility cannot fail to have its consequences in the peace settlement. As death and injury rained on the city, Jordan had become the source and origin of Jerusalem's fierce ordeal. The inhabitants of that city can never forget this fact, or fail to draw its conclusions."

U.N. Doc. A/PV. 1526, June 19 , at 50-5r.

${ }^{8}$ U.N. Doc. A/PV. 1554, at $4 \mathrm{r}$.

G.A. Resolutions 2253 and 2254, U.N. GAOR, 5th Emer. Spec. Sess., Supp. x, at 4, U.N. Doc. A/6798 $(1967)$.

${ }^{8}$ Exchange of letters between the Secretary-General of the U.N. and the Isracli Foreign Minister, July 15, I967, and Sept. II, x967, published in.U.N. Doc. A/6793, supra note 2, at 29, 30.

${ }^{9}$ See, e.g., Docs. A $/ 6743$, July 3,1967 , and $A / 6774$, July 25 , 1967 . See also remarks of Iraqi Delegation, U.N. Doc. A/PV. 1559 , Sept. 18,1967 , at $6-16$.

${ }^{10}$ U.N. Doc. A/6793, supra note 2, at 30. 
apparently, to deprivation of access to Holy Places in the Old City of almost all citizens of Israel from 1949 to 1967 , for instance to the Wailing Wall, and to acts of desecration of Jewish cemeteries. ${ }^{11}$

This reply should be viewed in the light of the conclusion of the United Nations Secretary-General, based on information supplied by his Personal Representative in Jerusalem," that it has been "made clear beyond any doubt that Israel was taking every step to place under its sovereignty those parts of the city" not previously controlled by Israel. ${ }^{13}$ Ambassador Thalmann reported that "The Israel authorities stated unequivocally that the process of integration was irreversible and not negotiable."14

The Personal Representative reported that he was told that "the Arabs recognize a military occupation régime as such and were ready to co-operate with such a régime in dealing with current questions of administration and public welfare. However, they were opposed to civil incorporation into the Israel State System," which action they regarded "as a violation of the acknowledged rule of international law which prohibited an occupying Power from changing the legal and administrative structure in the occuppied territory." The population of East Jerusalem "was given no opportunity to state for itself whether it was willing to live in the Israel State community." It was claimed that the right of self-determination, in accordance with the United Nations Charter and the Universal Declaration of Human Rights, had therefore been violated. ${ }^{15}$

The report of the Secretary-General dated September 12, 1967 indicates that "most of the Arabs interviewed" by the Personal Representative-Arab notables in Jerusalem, both governmental and religious-stated that the Muslim population "was shocked by Israel acts which violated the sanctity of Muslim Shrines."

Muslim leaders informed the Personal Representative that statements by Israeli officials and Jewish personalities "concerning Jewish claims and plans in the Temple area had had an alarming effect" on Muslim opinion. ${ }^{17}$ The dynamiting and bulldozing of 135 houses in the Maghrabi quarter (in front of the Wailing Wall) had also aroused strong feelings. This action involved "the expulsion of $65^{\circ}$ poor and pious Muslims from their homes in the immediate vicinity of the Mosque of Omar and the Aksa Mosque."18

In a letter of July 24, I967 the Israeli Military Governor for the West Bank was

\footnotetext{
${ }^{11}$ See U.N. Docs. A/7064 and A/7064/Add. I, March 6, 1968, a distribution of a pictorial document entitled "Desecration," issued by the Israeli Ministry of Foreign Affairs, Information Division, Jerusalem, November 1967 and transmitted to the Secretary-General of the U.N., March 5, 1968 .

${ }_{12}$ Ambassador Thalmann, a Swiss national. He arrived in Jerusalem on August 21, 1967, and departed on September 3, r967.

${ }^{23}$ U.N. Doc. A/6793, supra note 2 , at 7 .

14 Id.

${ }^{26}$ Id. at 24.

${ }^{10} \mathrm{Id}$. at $2 \mathrm{I}$.

${ }^{17} \mathrm{Id}$.

${ }^{18} \mathrm{Id}$.
} 
informed that the twenty-four signatories of the letter "had constituted themselves as the Naslim body in charge of Muslim affairs on the West Bank, including Jerusalem."19 "This 'Higher Muslim Council,' as it is also called, designated four Arab personalities to carry out the responsibilities of public administration . . . on the West Bank, including East Jerusalem, in accordance with the applicable Jordanian law." Eut the decisions of the "Higher Muslim Council" were not recognized by the Israeli authorities, although publicized to the Arab population through Amman radio. $^{20}$

The Secretary-General's Personal Representative in Jerusalem also reported the text of the statement issued June 27, 1967 by the Prime Minister of Israel concerning access to the Holy Places of Jerusalem and their administration. ${ }^{21}$ Also reported was the "Protection of the Holy Places Law," passed by the Knesset the same day,, as weli as the Prime Minister's statement of June 7, 1967 to spiritual leaders of all communities. $^{23}$ The statement of June 27 indicated that the Holy Places in Jerusalem "are now open to all who wish to worship at them-members of all faiths, without discrimination. The Government of Israel has made it a cardinal principle of its policy to preserve the Holy Places, to ensure their religious and universal character, and to guarantee free access." It was indicated that the policy would be carried out in consultation with representatives of the religious communities. The statctory measures provided for protection of the Holy Places from desecration and other violations.

The Personal Representative reported that these measures "were very favorably received," although some took a "wait and see" attitude. ${ }^{24}$ The Muslim reaction has been indicated above. The Catholic Church was reported as having essentially a divergent attitude to various other Christian denominations. The Holy See remained convinced that "the only solution which offers a sufficient guarantee for the protection of Jerusalem and of its Holy Places is to place that city and its vicinity under an international régime in the form of a corpus separatum."25

\section{III}

The United States and The Question of Jerusalem, 1967-68

On June r9, I967 the President of the United States said there must be "adequate recognition of the special interest of three great religions in the holy places of Jerusalem." ${ }^{28}$ On June 27, 1967 the Israeli Parliament approved legislation authorizing the Government to extend Israel's laws, jurisdiction and administration over addi-

\footnotetext{
${ }^{29}$ Id. at 44,46 .

${ }^{20} \mathrm{ld}$. at $22-23$.

21 Id. at 26 .

29 No. 5727-1967. Text printed in English, id.

${ }^{23}$ Id. at $25-26$.

24 Id. at 27.

${ }^{28}$ Id.

${ }^{20} 57$ Dep't State Bull. 33 (I967).
} 
tional territory of Eretz Israel ("the Land of Israel"). On June 28 the Government of Israel defined the Old City of Jerusalem and certain other territory of the former mandate of Palestine which had been under the control of Jordan since I948 as territory to be incorporated into an enlarged city of Jerusalem. ${ }^{27}$ On June 28 the White House indicated that the President "assumes" that "before any unilateral action is taken on the status of Jerusalem there will be appropriate consultation with religious leaders and others who are deeply concerned" and that "the world must find an answer that is fair and recognized to be fair."28 On June 28 , the Government of Israel took administrative action under the new legislation to extend its municipal services and controls over the entire city of Jerusalem. ${ }^{29}$ Later on that day a State Department press release ${ }^{30}$ read:

The hasty administrative action taken [by Israel] today cannot be regarded as determining the furure of the holy places or the status of Jerusalem in relation to them.

The United States has never recognized such unilateral actions by any of the states in the area as governing the international status of Jerusalem ....

On July 3, the United States Representative to the General Assembly said that "the safeguarding of the Holy Places, and freedom of access to them for all, should be internationally guaranteed."31

On July 7, Ig67 the Executive Committee of the National Council of Churches of Christ in the United States of America adopted a resolution ${ }^{32}$ which, in part, read:

With due consideration for the right of nations to defend themselves, the National Council of Churches cannot condone by silence territorial expansion by armed force. Israel's unilateral retention of the lands she has occupied since June 5 will only deepen the divisions and antagonisms which separate her from those neighbors in the midst of whom she must dwell.

The territorial frontiers of the states of the Middle East should now be definitely established by negotiation in treaties of peace and the integrity of such frontiers should be assured by international protection.

More specifically, on the issue of Jerusalem, the resolution of the National Council of Churches states:

We support the establishment of an international presence in the hitherto divided city of Jerusalem which will preserve the peace and integrity of the city, foster the welfare of its inhabitants, and protect its holy shrines with full rights of

\footnotetext{
${ }^{27}$ Measures summarized in U.N. Doc. A/6793, supra note 2, at 8.

${ }^{28} 57$ Dep't State Bull. 60 ( 1967 ).

20 See note 27 supra.

so 57 Dep't State Bulz. 60 (196\%).

31 U.N. Doc. A/PV. 1546, July 3, 1967, at 3-5.

as Memorandum entitled "Resolution on the Crisis in the Middle East." See N.Y. Times, July 15, 1967 , at 28 , col. 1 .
} 
access tc all. We encourage the earliest possible advancement of U.N. proposals to make such arrangements practicable.

We zannot approve Israel's unilateral annexation of the Jordanian portions of Jerusalem. This historic city is sacred not only to Judaism but also to Christianity and Islim.

On Jusy I4, Ambassador Goldberg, speaking for the United States Delegation to the Fifth Emergency Special Session of the U.N. General Assembly, reiterated that "the United States does not accept or recognize . . . as altering the status of Jerusalem" the measures taken by the Israeli government on June 28. He said further that the United States did not recognize that these measures

can be regarded as the last word on the matter, and we regret that they were taken. We insist that the measures taken cannot be considered as other than interin and provisional, and not as prejudging the final and permanent status of Jerusalem.

Unfortunately, and regrettably, the statements of the Government of Israel on this matter have thus far, in our view, not adequately dealt with this situation. ${ }^{33}$

Nevertheless, the United States abstained from voting on General Assembly resoIution $\mathrm{A} / 2254{ }^{34}$ the resolution not fully corresponding to United States government views, particularly since, even as revised

it appears to accept, by its call for rescission of measures, that the administrative miasures which were taken constitute annexation of Jerusalem by Israel, and because $w=$ do not believe that the problem of Jerusalem can realistically be solved apart from the other related aspects of the Middle Eastern situation.

The:e are, it was said, important practical issues in addition to "transcendent spiritual interests" that must be resolved. The United States representative implied that the Assembly should have gone no further than to declare itself against any unilateral change in the status of Jerusalem..$^{35}$

Following reports in January 1968 of Israeli plans for development of certain areas of the occupied sector of Jerusalem-being between Mt. Scopus and the former armistice line-a State Department spokesman reiterated that the United States does not recognize "any unilateral actions affecting the status of Jerusalem." ${ }^{36}$ The United States position is that Arab territories now administered by Israel as a result of the six-day war should be administered under the law of occupation as recognized by international law, not under a right of conquest. The Department of State apparently regards the Hague Convention of 1907 as applicable to the existing situation. $^{37}$

\footnotetext{
${ }^{33}$ U.N. Doc. A/PV. 1554, July 14, 1967, at 48.

ss Note 6 supra and accompanying text.

${ }^{35}$ U.N. Doc. A/PV. 1554, stipra note 33 , at 48,51 .

${ }^{85}$ N.Y. Times, Jan. 16 , r968, at 16 , col. 6 .

${ }^{37}$ For some recent statements as to rules considered applicable, see I M. Winteman, Digest of InTERNATIONAL LAW 946-52 (r963).
} 
IV

\section{Some Legal and Political Questions}

A question has been raised as to whether acquisition of territory by conquest is valid in the light of the United Nations Charter obligations accepted by both sides. Press reports frequently refer to "territory conquered," but the Israeli government has apparently avoided making a claim on that basis. Does the integration of Arab Jerusalem by Israel hurt the prospects for an agreed settlement of larger aspects of the Arab-Israeli confrontation? What is the legal meaning and the political effect of Israel's contention that the future of Arab Jerusalem is not negotiable? Have Israel's leaders concluded that the prospects for a settlement with the Arab states are so unlikely, because of Arab intransigence; that the integration or annexation of Jerusalem does not actually endanger prospects for a peace settlement, because the prospects for the foreseeable future, despite efforts of the Secretary-General's Special Representative, Dr. Gunnar Jarring, are hopelessly dim?

It may be useful to divide the Jerusalem question into three major aspects: (I) who will govern Jerusalem-i.e., whose "law, jurisdiction and administration" will prevail in the future? Will the city remain unified as it was prior to 1948 and in $1967-68$ or again be divided? Or will it be managed in a third way? And will the determination be made by unilateral action or by agreement? (2) What arrangements can be made to assure "adequate recognition of the special interest of three great religions in the holy places of Jerusalem," i.e., to guarantee the protection of the Holy Places within and outside Jerusalem and for assurance of access thereto? (3) Should an international presence be maintained in Jerusalem with functions broader than that of protecting the holy places? What practical proposals can be agreed to and maintained in the face of diverging interests? These are difficult political questions which confront or may confront the interested governments. The answers can best be found through the process of negotiation. Recognizing that such negotiations must inevitably be affected by other questions lying beyond the scope of this paper, let us consider certain background facts that help put the present situation in perspective.

\section{A. Political}

How does the experience of history relate to these questions? A quick look may give a distorted image, but hopefully may suggest essential reality if only approximate. Who has governed Jerusalem and how was title gained? In the past $35^{00}$ years the city has changed hands more than twenty-five times. ${ }^{38}$ We can begin with David who about rooo B.C. captured the old Jebusite Town and claimed it as the City of David. Later it was conquered by one empire after another-Babylonian,

${ }^{38}$ S. Perowne, The One Remains it (i954). See also Report of the Commission appointed by

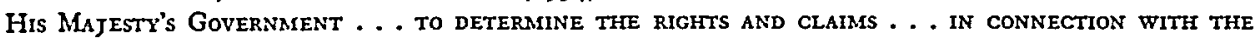
Western or Wailing Wall at Jerusalem: December I930, at 9-15 (I931). Distributed as U.N. Docs. A/7057/Add. I and S/8427/Add. I, Feb. 23, I968. 
Persian, Macedonian, Ptolemy, Selucid, and Roman. In 638 A.D. the Caliph Omar captured Jerusalem for Islam. Later it was held by Seljuk Turks, by Christian Crusaders, and by Egyptian Mameluks. From 1517 to 1917 Jerusalem was ruled by the Ottoman Turks, who then gave way to General Allenby of Great Britain. Following World War I, the Principal Allied Powers decided that Palestine should be a League of Nations mandate assigned to Great Britain. On July 24, 1922 the Council of the League of Nations confirmed and defined the terms of the Mandate for Palestine, with Great Britain as the Mandatory Power. The Palestine Mandate went into effect September 29, $1923 .{ }^{39}$ When it terminated on May 15, 1948 Arabs and Jews of Palestine, and Arab armies from without, fought for possession of Jerusalem and of Palestine. The outcome confirmed the reality of what actually had already become a divided city, now occupied by Israeli and Jordan authorities, ${ }^{40}$ with a set of conflicting claims, which, in turn, conflicted with plans and proposals of the United Nations to establish Jerusalem as a corpus separatum under an internanational régime. This proposal was part of the Plan of Partition with Economic Union, which was recommended by the General Assembly on November 29, $1947^{41}$ in an effort to provide for the future government of Palestine, upon the termination of the British Mandate. This Plan was never fully implemented. ${ }^{42}$

A: no time did the international community acting through the United Nations recornmend that the City of Jerusalem or a portion of it be assigned to either Israel or Jordan. The claims of those two countries that they were rightful sovereigns of their parts of Jerusalem, while recognized by some states, have not been recognized by others, including the United States, the United Kingdom, France, and the Soviet Union, all of which continued to maintain embassies in Tel-Aviv and Amman. ${ }^{43}$

During 3000 years of history, control over Jerusalem has been almost invariably acquired by conquest.

\section{B. Protection of and Access to the Holy Places}

The historical record shows that Jerusalem has long been regarded as a place of religious significance to the adherents of three world religions all of which seek protection of their interests. Jerusalem has been revered by Jews for 3000 years, by Christians for nearly 2000, and by Moslems for more than 1300 years. Many of the shrines represent a common inheritance of three religions. Even the name of the city in Arabic (Al-Quds) means "The Sanctuary." Although it has been said

\footnotetext{
${ }^{30}$ For text see CMid. No. 1785 (1923).

${ }^{30}$ P. De Azcarate, Mission in Palestine 1948-i952, at 182 (ig66).

${ }^{41}$ G.A. Res. 181, 2 U.N. GAOR, Resolutions 131, 132 (1947).

12 See I M. Whitexian, supra note 37 , at 699, 701, 703.

${ }^{43}$ Id. at $594,595,699$.

"4. Mohn, Jerusalems aNd the UNited Natrons 427 (International Conciliation pamphlet no. ${ }_{4}^{6} 4$, October 1950).
} 
that "the business of Jerusalem is eternity," its spiritual significance as a city of God, of peace and of brotherly love, has been sadly tarnished by bloodshed, political intrigue and bitter rivalry for the privilege of protecting or adminstering the holy places and shrines. Religious emotion or even fanaticism has at times been exploited by temporal rulers who sought exclusive advantages not primarily those of spiritual uplift or human betterment. The diversity of religious interests-Moslem, Catholic, Jewish, Orthodox, Armenian, Coptic, Abyssinian, Syrian, Anglican and other Protestant, and with institutions established by religious bodies in Europe, Asia, Africa, and the Americas-called for some system of order and protection. In 1757 the so-called Status $Q u t o$ was established to this end. Thereafter, Moslem temporal power, on the whole, did not interfere with the management of the Holy Places, but there were claims and counter-claims. ${ }^{46}$ The system did not change greatly under the British Mandate, which in Article 13 specified that the Mandatory should preserve existing rights in connection with the Holy Places. But at times, such as 1929 , there was serious rioting. ${ }^{47}$

\section{Proposals for International Régime}

When on November 29, 1947 the United Nations General Assembly recommended partition of Palestine into a Jewish state and an Arab state with Economic Union, it was recommended that the city of Jerusalem (including the existing municipality plus the surrounding villages and towns such as Bethlehem) be established as a corpus separatum, under a special international régime, to be administered by the Trusteeship Council on behalf of the United Nations. This régime was to include the appointment of a Governor, responsible to the Trusteeship Council, the establishment of a special police force whose members were to be recruited from outside of Palestine, the election of a legislative Council, and the demilitarization of the city. ${ }^{48}$ "Jerusalem was envisaged as a model city, a spiritual center, a seat of learning, the influence of which could help to overcome the national and religious animosities and prejudices which for so many years have poisoned the atmosphere of the Holy Land." ${ }^{\prime 9}$ The proposal for a corpus separatum seemed sensible since the General Assembly's Plan of 1947 separated Jerusalem from the proposed Jewish state by a strip of intervening Arab territory assigned to the proposed Arab state. Jerusalem under the 1947 Plan would have been a city of approximately equal Arab and Jewish population, with the Moslem Arabs somewhat more numerous than the Christian Arabs.

\footnotetext{
¿ Perowne, supra note 38 , at 13 .

${ }^{10}$ Report of the Commission .... supta note 38, at 15-22; W. Eitan, The First Ten Years 66 (1958); Monn, supra note 44 , at $433-38$.

${ }^{17}$ C. Sykes, Crossroads to Israel io8-11 (1965).

${ }^{18}$ See Part III of the Plan, supra note 4I; Extan, supra note 46 , at 68-69. For map showing the proposed boundaries of Jerusalem, see annex B attached to the Plan.

"MoHn, supra note 44 , at 451 . (Emphasis added.)
} 
A stat ste for Jerusalem had been drafted by the Trusteeship Council in the spring of $1948,{ }^{50}$ but formal adoption was postponed owing to the state of confusion into which the larger question of Palestine had been thrown by the fighting already in progress and uncertainty as to whether the November 29, 1947 Plan could be implemented. ${ }^{51}$ The Arab Higher Committee had rejected the Partition Plan in its eritirety; the Jewish Agency accepted it under protest. No international authority had been created to take the place of the British Mandatory authority in Jerusalem which had been supported by British troops for twenty-five years. These were about to depart on May 14, 1948 as the British Government had repeatedly affirmed. Yet it had been clear for months that the Partition Plan with Economic Union could not be implemented by agreement, and it could not be implemented by force alone, since it called for economic cooperation. The Plan was clearly unworkable in the light of political realities.

The divergent policies of the Powers blocked agreement in the United Nations, not of a "definition of the International interest" in Jerusalem, but of a concerted will to implement internationally-defined policy against firm resistance. International policy, defined and redefined by the General Assembly resolutions in $1947^{52} 1948^{53}$ and $I 949^{54}$ but not consistently supported by necessary action, was brushed aside by the national policy of a few states with clear goals. Christopher Sykes aptly refers to the "melee of conflicting British and American attempts at policy." The draft statutes of an international régime in Jerusalem, although at least in one case directed to be put into effect despite opposition of Israel and Jordan, were not put intc. effect, and "came to nothing" in the world of action. Jordanian and Israeli armed forces took and retained control of their respective parts of Jerusalem filling a racuum with national power. A new kind of status quo was maintained in Jerusalem, following the Israeli-Jordan Armistice Agreement of $1949,{ }^{56}$ until it was again upset by force in June 1967 .

When the United Nations Conciliation Commission for Palestine ${ }^{5 \pi}$ realized the impossibility of setting up a genuine international régime (based on the idea of a corpus separatum) and drafted a modified statute in $1949^{\text {.5 }}$ compatible with the fait accompli of the partition of Jerusalem between Israel and Jordan, it remained

\footnotetext{
${ }^{50} 3$ U.N. TCOR, 2d Sess., pt. 3, Annex, at 4, U.N. Doc. T/118/Rev. 2 (1948).

${ }_{52}$ Proceedings summarized in Annual Report of the Secretary-General on the Work of the Organization, I July I947-30 June 1948, 3 U.N. GAOR, Supp. I, at 4-5, U.N. Doc. A/565 (1948). See also MoH:, supra note 44 , at $455-56$; E ETAN, stipra note 46 , at 70 ; AzcARATE, supra note 40 , at $184-85$.

${ }^{22}$ G.A. Res. $18 \mathrm{r}$, supra note 41 .

${ }^{53}$ G.A. Res. I94, para. 8, 3 U.N. GAOR, pt. 1, Resolutions 21, 23, U.N. Doc. A/810 (1948).

st G.A. Res. 303, 4 id., Resolutions 25, U.N. Doc. A/125I (I949).

Es Srkes, stipra note 47, at 357. See also Report of the Trusteeship Council entitled "Qucstion of an International Regime for the Jerusalem Area and the Protection of the Holy Places," 5 U.N. GAOR, Supp. 9, U.N. Doc. A/1286 (I950).

${ }^{60} 42$ U.N.T.S. 303 , no. $656 ; 4$ U.N. SCOR, Spec. Supp. I, U.N. Doc. S/1302/Rev. I (1949).

57 Established by G.A. Res. I94, supra note 53 .

${ }^{88} 4$ U.N. GAOR, Ad Hoc Pol. Comm., Annex., vol. I, at ro, U.N. Doc. A/973 (1949).
} 
only a "blue-print," although one worthy of study both then and now. The draft sent to the General Assembly September I, r949 was "pigeon-holed without even being accorded the honor of a debate," as a result of the pressure of various delegations. Some, sympathetic with the Vatican's point of view, "were not prepared to accept anything less than integral and complete internationalization." 59 All of the Arab states except Jordan also sought a more thorough-going internationalization.

Israel, on the other hand, was antagonistic because the Conciliation Commission's plan involved too much international control. The Israeli government argued that the plan ignored the "physical facts" and "deeper truths of sentiment and allegiance," adding that "For the first time in modern history, political authority in the greater part of Jerusalem rests not on military conquest but on the will and consent of the population of the city." mission was responding to the General Assembly's Resolution I94(III) of December II, I948 wherein the General Assembly had decided that the Jerusalem area should be accorded "special and separate treatment from the rest of Palestine" and that it should be placed "under effective United Nations control." Israel's policy did not support that objective: it favored national control of Jerusalem, its new capital, in a nation re-created after decades of struggle under Zionist leadership, catapulted to birth by the agony produced by the Nazi slaughter of millions of European Jews.

\section{V}

\section{Reflections on the Present}

\section{INTERNATIONAL SYSTEM AND JeRUSALEM's FUTURE}

The future status of Jerusalem is obviously related to the larger question of the fundamental characteristics of the future international system of the Middle East. As for the international system of the past two decades, of which international law is only a part, if we judge it primarily by the practice of states rather than by the proclaimed principles which states affirm as principles that ought to be applied, we can only conclude that the use of force in pursuit of national policy is not altogether ruled out. Almost invariably when force is used, the claim of the exercise of the right of self-defense is asserted, and sometimes justified. The Arabs of Palestine asserted the right of self-defense in I948 against the Partition Plan, adopted as a recommendation of the General Assembly. They regarded the Plan as immoral and illegal. ${ }^{61}$ The Israeli Government asserted the right of self-defense to maintain

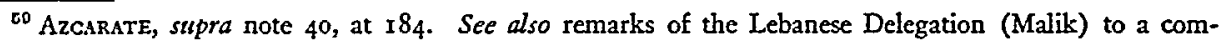
mittee of the General Assembly on May 5, 1949, 3 U.N. GAOR, pt. 2, Ad Hoc Pol. Comm. 219-26.

${ }^{60}$ Memorandum on the Future of Jerusalem, prepared by the Israeli Delegation, Nov. 15, 1949, at 2, U.N. Doc. A/AC.3I/L. 34. See also remarks by the Israeli Delegation (Eban), 3 U.N. GAOR, pt. 2, Ad Hoc Pol. Comm. 230-37 (x949).

${ }^{01}$ The Arab Higher Commitee contended, at the 2d Special Session of the General Assembly, in April 1949, that the Mandate for Palestine disregarded the right to self-determination, and that the Arabs had no alternative but "to resort to the sacred right of self-defense." The Arabs had done "what any
} 
national identity threatened by Arab governments in $194^{8}$, in $195^{6}$, and again in 1967. ${ }^{62}$ The United Nations did not clarify the legal situation that existed.

In this existing international system-this system more political than juridical, this system that does not assure the rule of law or international security by collective measures :o frustrate a breach of the peace-perhaps the best hope for progress towards peace and security must rest with the policies of states which surely must increasingly understand the unwisdom of continued belligerency and war. While some wars can be deterred by threat of force or reprisal, the basic Middle East problem calls for other approaches. The great imperative is for a changed approach, a new attitude on both sides, which will permit the leaders of both sides to show greater understanding of the fears, the needs, and the legitimate interests of other states. This line of thinking brings us back to the idea that governments as well as leaders of public opinion should respond to the over-riding need for national self-restraint, fairness to others, and for easing tensions between nations, thereby assisting the growth of a new spirit of confidence that men can act more wisely in the future for peace and justice. It is a new vision of the practical advantages that will accrue to those who accept a community of mutual rights and responsibilities that is needed, not a continued devotion to political myths that insist on national or group exclusiveness and enmity. On what other basis can we hope for a solid political foundation on which to develop a more adequate international law?

Surely the present need is for a more realistic understanding by peoples generally of their national and regional interests. Hostility, belligerence, non-recognition of the right of neighboring states to exist, and disregard of the rights of others to territorial integrity are basic causes of insecurity for all. Perhaps it would help in resolving the problem of Jerusalem if the parties most concerned would not overemphasize the importance of political images of Jerusalem formed centuries ago in a very different age. Historic national dreams, perhaps vital in ages past, may need updating if the fundamental interests of the peoples of our time are to be advanced. Imagine the benefits that would flow if nations would discard from national myths that which is provocative and unjust to others, thereby facilitating the growth of the more constructive aspects of nationalism and encouraging healthy international cooperation. The Jerusalem question, if viewed with this spirit, with everyone avoiding malice and vituperation, might gradually be transformed to more optimistic proportions, with reduced likelihood that Jerusalem will be in the future, as it has been all too often in the past, a center for pathetic rivalry and a continuing object of re-conquest, perhaps headed once again for destruction.

other Member State would have done" fought in self-defense. The Partition resolution was "ill-advised," "illegal," and "could not be carried out." U.N. GAOR, 2d Spec. Sess., vol. II, Main Committees 93 (I948).

${ }^{2}$ See remarks by the Israeli Minister for Foreign Affairs (Eban) to the Security Council, U.N. Doc. S/PV. I375, Nov. 13, 1967, at 6-36; Israel's Struggle for Peace, chs. VIII, IX and X (Israel Office of Information, New York, 1960). 
This is the time for states generally to support the efforts of the United Nations Special Representative, Dr. Jarring, as he explores with the parties most directly concerned the broader dimensions of peace-making in the Middle East. ${ }^{e 3}$ Will the Arab states and Israel work to establish the foundations for peace in the spirit of that resolution? Or will shortsighted, particularistic interests of states sidetrack progress toward an agreed settlement by inducing them to nullify one or the other of the basic principles adopted unanimously in the Security Council resolution of November 22, $1967^{?^{64}}$ It is acceptance of the entire package which is a valid test of one's interest in peace with justice. At least this seems to have been the view of the Security Council.

One would hope that the world will not experience disappointment similar to that of 1947-1952, when an opportunity for a peaceful resolution of the Arab-Israel problem foundered. Every nation's stake in moving toward peace based on agreement is enormous. This is the prerequisite for strengthening international law in the Middle East, in view of such conflicting definitions of justice as have been spread on the United Nations record for the past twenty years.

If a new appreciation of national self-interest can be developed in the months ahead, based on a wider recognition of the futility of Middle Eastern politics of recent years, presumably some agreements would become possible. It should then become possible to agree on an acceptable formula of "the national and international interest" in Jerusalem, which could then be guaranteed by the principal Powers. The balancing of interests and claims in the Middle East becomes an imperative, in view of the uncertainties of law and the facts of power, if some tolerable stability is to be achieved. The definition of justice in such a politically divided area could hardly be expected to conform to the fullest expression of national aspirations and national morality-either Arab or Israeli. A rational solution calls for a negotiated settlement (sooner rather than later) under the auspices of a third party utilizing any arrangement agreeable to the parties most concerned, and, failing that, under an arrangement determined by the Security Council.

In the interest of long-run cooperation among the peoples and nations of the Middle East, it is believed that the advantages of a corpus separatum for the walled City of Jerusalem could be a desirable goal for the overwhelming majority of the members of the United Nations, and would probably serve the higher, long-range interests of Israel and Jordan. To achieve this objective, it might become desirable for the states of the world to recognize West Jerusalem as the capital of the state of Israel. So much of Israeli nationalism is centered on Jerusalem as a focal point in national political life that it would seem practical to accept this reality. However,

\footnotetext{
${ }^{83} \mathrm{~A}$ recent statement of relevant U.S. policy was made on Dec. 8,1967 , by the Under Secretary of State for Political Affairs, Eugene V. Rostow, 58 Dep't State Bull. 4 I (ig68).

' For text of Resolution 242, see Rosenne, in this symposium, pp. 44, 56.
} 
this line of thinking would reserve the walled city as an International Zone-a corpus separatum, but would not necessarily be restricted to it. ${ }^{65}$

These concluding ideas do not constitute a proposal for the future status of Jerusalem. They are suggested only as possible ideas for consideration by those concerned. Both a national and an international presence would be embraced in a greater Jerusalem. An international statute would once again be drafted, and would constitute a part of the peace settlement hopefully to grow out of Ambassador Jarring's step by step efforts to build a peace on the principles of the Security Council's Resolution 242 of November 22, I967.

But are these ideas practical? They could become practical, when carefully revamped by legal and political experts-if, but only if, the parties most concerned will re-evaluate their national interests in harmony with the greater need for genuine peace. The future of Jerusalem is inevitably entwined with the larger aspects of Arab-Israeli relations. In March 1968 serious violations of the cease-fire which brought renewed consideration by the Security Council confirmed earlier impressions that the prospect for genuine peace and for a rule of law in the Middle East seemec as elusive as ever. In the interest of international peace and security, perhaps the time is near when the Security Council will act to assert its authority under the Charter. ${ }^{66}$ If not, the outlook seems one of continued belligerency, bitterness, and danger. The Middle East is faced with important choices in 1968 . We can do no other than to hope for a new vision grounded in justice and focusing on a better day.

\footnotetext{
${ }^{35}$ See proceedings regarding Jerusalem in the Trusteeship Council 19+9-1950, summarized in the spe:ial report cited supra note 55. See especially Private Memorandum from the Archbishop of Canterbury, Oct. 3I, I949, id. at 9-II. The Statute for the City of Jerusalem approved by the Council, April 4, 1950, is set forth id. at I9. See also Darin-Drabkin, Jertusalem-City of Dissension or Peace?, New OutLOJK: Middele EAST MoNThIY, Jan. 1968, at 12, for an Israeli interpretation.

${ }^{60}$ On May 2r, 1968 the U.N. Security Council alopted Resolution 252 on Jerusalem; for tcxt, see El-Farra, in this symposium, pp. 68, 73.
} 